\title{
Community Political Participation in Kuantan Singingi Regency Head General Election During the 2020 Covid- 19 Pandemic Era
}

\author{
Sudaryanto Sudaryanto ${ }^{1}$, Ruslyhardy Ruslyhardy ${ }^{2}$ and Iwan Arasit ${ }^{3}$ \\ 1,2,3 Universitas Lancang Kuning, Pekanbaru, Indonesia \\ sudaryantofia@unilak.ac.id
}

\begin{abstract}
In Indonesia, one of the regencies/cities that have carried out the Regional Head Election is Kuantan Singingi Regency, which was on September 9, 2020, but the number of voters has decreased. This problem is related to health, economy and human resources. Public political participation in general can be categorized in several forms, namely; election activities, trying to influence, organizational activities, seeking connections and acts of violence. This research is qualitative using descriptive analysis approach. Research informants are the Chair of the General Election Commission, the Chair of the Election Oversight Body, academics, election activists and community leaders. As a result, voter participation has decreased due to the lack of optimal election education activities and concerns about the spread of the corona virus.
\end{abstract}

Keywords: Participatio, Voter, Covid-19

\section{Introduction}

In Indonesia, one of the regencies/cities that have carried out the Regional Head (henceforth: Pilkada) Election is Kuantan Singingi Regency, namely on September 9, 2020. This election is the beginning of the creation of democratization and local political culture in the political system in Kuantan Singingi Regency. According to political expert Arbi Sanit, there are three interest groups in the Pilkada. Namely (a) the interests of the national political elite, (b) the interests of the local elite, (c) the interests of the common people. Several regions in Indonesia that have held local elections for governors or regents/mayors have left many notes on the development and sustainability of democracy. One of the pillars mentioned by Arbi Sanit is that the interests of the people in general are drowned out by the domination of the interests of the elites who fought in the Pilkada (Priyono et al., 2007, p. 74).

From the results of field observations, it can be seen that the people in Kuantan Singingi Regency are less enthusiastic about participating in the local democratic party in the 2020 Pilkada during the Covid-19 Pandemic. The political participation of the people that is very easy to observe is the voting or voting rights of the community for the candidate pairs for the Regent and Deputy Regent in the 2020 Kuantan Singingi Regency Election which consists of three Candidate Pairs, namely:

1. Andi Putra, SH, MH \& Drs. H. Suhardiman Amby, Ak, MM

2. Drs. H. Mursini, M.Si \& Indra Putra, ST. 3. H. Halim \& Komperensi, SP, M.Si.

The three pairs of candidates for Regent and Deputy Regent above consist of different backgrounds and various professions, some are from Bureaucrats, Politicians and Entrepreneurs. From the results of the recapitulation of the Kuantan Singingi Regional General Election Commission, it was recorded that the three pairs of candidates for Regent and Deputy Regent who were ranked the highest were the pair of Andi Putra-Suhardiman Amby with a percentage of $44.12 \%$, MursiniIndra Putra with a percentage of $23.13 \%$ and Halim-Komperensi with a percentage of $32.75 \%$. 
The holding of the 2020 elections during the Covid-19 pandemic has challenges, both in terms of technical and quality of implementation. The technical challenges of holding regional elections during the pandemic are closely correlated with the procedures for implementing them at all stages of adjusting health protocols, as a consequence the General Election Commission must be able to adjust them, one of which is for socialization activities. All stages of the Pilkada must implement the Covid-19 prevention health protocol, one of which is socialization. Socialization as an effort to convey political education to the public is a challenge for Pilkada organizers, namely how to encourage public awareness to use their political rights responsibly and vote rationally. In addition, of course, encouraging voters to come to the polling station (TPS) by ensuring that the polling stations are safe with the implementation of strict health protocols to prevent the spread of Covid-19.
The benchmark for the success of holding simultaneous regional elections on December 9, 2020 is determined from the enforcement of discipline in implementing health protocols so that there is no transmission of Covid-19 cases. This is the main responsibility of election organizers and all candidate pairs to ensure the 2020 Simultaneous Regional Head Elections can run smoothly and safely in the midst of the Covid-19 Pandemic. The General Elections Commission (KPU) has issued various regulations emphasizing the importance of implementing health protocols at all stages of this election, including during voting at Polling Stations (TPS).

During the Covid-19 Pandemic Period in the Kuantan Singingi Regency area, it had an impact on the economic, social, political fields, including the juridical impact on democratic life in the General Election of the Regional Head of Kuantan Singingi Regency in 2020. The following is data on the spread of Covid-19 in Kuantan Singingi Regency which confirmed in 2020 to 2021:

Table 1

Covid-19 Spread Data

\begin{tabular}{llc}
\hline No & \multicolumn{1}{c}{ District } & Number \\
\hline 1 & Benai District & 18 \\
2 & Pangean District & 33 \\
3 & Kuantan Hilir District & 36 \\
4 & Kuantan Hilir Seberang District & 2 \\
5 & Inuman District & 12 \\
6 & Cerenti District & 32 \\
7 & Singingi District & 92 \\
8 & Singingi Hilir District & 83 \\
9 & Gunung Toar District & 8 \\
10 & Hulu Kuantan District & 19 \\
11 & Kecaatan Pucuk Rantau District & 16 \\
12 & Kuantan Tengah District & 372 \\
13 & Logas Tanah Darat District & 41 \\
14 & Sentajo Raya District & 46 \\
15 & Kuantan Mudik District & 60 \\
\hline & & $\mathbf{8 7 0}$ \\
\hline & & Total
\end{tabular}

The following is the data on the recapitulation of vote acquisition for each pair of regional head candidates during the
2020 Kuantan Singingi Regency General Election: 
Sudaryanto Sudaryanto, Ruslyhardy Ruslyhardy and Iwan Arasit / Community Political Participation in Kuantan Singingi Regency Head General Election During the 2020 Covid-19 Pandemic Era

Table 2

Vote Recapitulation Data

\begin{tabular}{llccc}
\hline No & \multicolumn{1}{c}{ District } & Number 1 & Number 2 & Number 3 \\
\hline 1 & Benai District & 3.817 & 2.132 & 2.713 \\
2 & Pangean District & 4.989 & 2.654 & 2.140 \\
3 & Kuantan Hilir District & 3.988 & 1.365 & 1.705 \\
4 & Hilir Seberang District & 3.519 & 906 & 1.775 \\
5 & Inuman District & 6.331 & 640 & 1.178 \\
6 & Cerenti District & 3.165 & 1.983 & 2.228 \\
7 & Singingi District & 5.198 & 2.219 & 6.898 \\
8 & Singingi Hilir District & 3.968 & 2.465 & 10.216 \\
9 & Gunung Toar District & 2.180 & 4.608 & 901 \\
10 & Hulu Kuantan District & 1.904 & 1.400 & 1.551 \\
11 & Pucuk Rantau District & 1.815 & 1.238 & 684 \\
12 & Kuantan Tengah District & 9.406 & 7.095 & 8.526 \\
13 & Logas Tanah Darat District & 5.506 & 1.158 & 4.073 \\
14 & Sentajo Raya District & 9.884 & 2.117 & 5.329 \\
15 & Kuantan Mudik District & 4.613 & 5.005 & 2.466 \\
\hline & $\quad$ Total & $\mathbf{7 0 . 2 8 3}$ & $\mathbf{3 6 . 9 8 5}$ & $\mathbf{5 2 . 3 8 3}$ \\
& & $\mathbf{( 4 4 , 1 2} \%)$ & $\mathbf{( 2 3 , 1 3 \% )}$ & $\mathbf{( 3 2 , 7 5 \% )}$ \\
\hline
\end{tabular}

Source: The results of the open plenary recapitulation and determination of the results of the vote count at the Regency level for the 2020 Kuantan Singingi Regent and Deputy Regent election.

As a comparison material for the level of voter participation in the post-conflict local election in Kuantan Singingi Regency in 2020, the researchers presented data on community participation in several periods of regional head elections, governor elections, legislative elections and direct presidential elections from 2015 to 2020 .

Table 3

Voter Data for the 2015 to 2020 General Elections and Regional Head Elections

\begin{tabular}{cllcc}
\hline No & Implementation Year & \multicolumn{1}{c}{$\begin{array}{c}\text { Number of } \\
\text { Permanent } \\
\text { Voters }\end{array}$} & $\begin{array}{c}\text { Number of } \\
\text { Voting Rights } \\
\text { Users }\end{array}$ & $\begin{array}{c}\text { Percentage of } \\
\text { Voter } \\
\text { Participation } \\
(\%)\end{array}$ \\
\hline 1 & 2015 Pilkada & 224.373 & 161.459 & $73,85 \%$ \\
2 & 2018 Pilkada (Pilgub) & 211.082 & 153.076 & $72,52 \%$ \\
3 & $\begin{array}{l}\text { 2019 General Elections } \\
\text { (Pemilu) }\end{array}$ & 224.898 & 189.769 & $84,38 \%$ \\
4 & 2020 Pilkada & 232.877 & 162.483 & $69,94 \%$ \\
\hline : Results of Data Recap from the Regional General Election Commission of Kuantan Singingi Regency.
\end{tabular}

Based on the data that the author collects and the author's observations in the field, the problem is:

1. Health Protocol; Technically, adjusting the election organizers to health protocols in the midst of a pandemic is not an easy matter. This is because the organizers envision and target the success of the election, while the voting community gathers at the existing TPS. Of course, due to the COVID-19 pandemic, crowds were prohibited, so that the implementation of the regional elections had to redesign the technical implementation, with reference to health protocols.

2. Economy; With the outbreak of the Covid-19 Pandemic in the world, including Indonesia, which has an impact on the instability of the national economy which has a direct impact on society. Economic problems are indeed a basic problem for society, this is a very influential thing on voter participation, 
because if the needs are met all affairs will be felt to be easy and smooth.

3. Human Resources; Every organization or company needs resources to achieve its goals. The level of public participation in voting during the Covid-19 Pandemic in the 2020 Regional Head Election decreased compared to the 2015 General Election.

The theoretical concept is a relevant theory that can be used to explain the variables to be studied and researched, as well as a basis for providing temporary answers to the problem formulation proposed as a hypothesis (Sugiyono, 1998, p. 200). While the theoretical framework is a series of conceptual assumptions, abstracts and propositions to explain a social phenomenon systematically by formulating the relationship between one concept and another.

The centralization of power centered in Jakarta for more than 32 years of the New Order government is now being undermined by the process of deregulation, privatization and political decentralization. This phenomenon, for example, was marked by the enactment of Law 32 of 2004 concerning regional government which replaced Law 22 of 1999 and Law number 23 of 2014. The law encouraged widespread political localization and spread throughout the country. Along with this process, political power is also increasingly being distributed significantly to local governments. In short, decentralization has created a process of political localization and the formation of new political spaces and arenas at the local level (Priyono et al, 2007, p. 127).

In this law, the central government gives authority to regions or districts/cities throughout Indonesia to administer and manage their own household. Decentralization and regional autonomy are one unit that influence the formation of local political systems. To be clear, what is decentralization and regional autonomy, literally, decentralization means away from the center (away from the center). From a political perspective, it means the transference of authority, legislative, judicial, or administration, from a higher level of government to a lower level or the devolution of central government power to local government or the transfer of power and accountability to local governments on the grounds that local governments have the ability to pay attention. responsiveness) and accountability because local governments are closer to their citizens to provide public services (Hamdi, 2006).

According to Mas'oed \& MacAndrews (2008, p. 225) public political participation in general can be categorized in several forms as follows:

1. Electoral Activities, namely all forms of activities directly or indirectly that include voting, campaign donations, working in an election, seeking support for a candidate or any action aimed at influencing the outcome of the election process.

2. Trying to influence (Lobbying) which includes individual or group efforts to contact government officials and political leaders with the intention of influencing them regarding certain issues.

3. Organizational Activity, namely the involvement of citizens in social and political organizations, whether they are leaders, activists, or as ordinary members whose main purpose is to influence government decision-making.

4. Looking for Connections, namely participation by the community directly with government officials or political figures, either individually or in small groups of people with the intention of obtaining benefits for a few people.

Violence, namely as an effort to influence government decision-making by means of violence that causes physical harm to people or property.

\section{Method}

According to Moleong (2007), the research method defines the research location as where the researcher conducts research, in which the researcher finds and clearly captures events and field phenomena 
that actually occur for real, so that researchers objectively describe field results in the thesis accurately. based on data. This research was conducted at the Regional General Election Commission (KPUD) of Kuantan Singingi Regency as well as other institutions that became the main sources in this research such as the Election Supervisory Body (Bawaslu) of Kuantan Singingi Regency.

This research is qualitative in nature using a descriptive analysis approach, which is a method that provides an overview and explanation of phenomena or situation descriptions based on existing data. Then it is continued by interpreting as a measuring flow to explain and analyze certain factors on the problem under study and finally try to predict it. While the type of research used in this study is field research.

To test the truth of the research empirically, the researcher used descriptive qualitative data analysis techniques, so that they could explain the law of causality or cause and effect that affects the factors of participation and the tendency of the form or typology of community voters. This descriptive analysis begins with data collection, data presentation, empirical data analysis and ends with drawing conclusions.

\section{Results and Discussion \\ 3.1 Electoral Activity}

Election activities are all forms of activities directly or indirectly that include voting, campaign contributions, working in an election, seeking support for a candidate or any action aimed at influencing the outcome of the election process. Based on the results of the research, the level of Community Participation in the 2020 Regional Head Election during the Covid-19 Pandemic yesterday decreased compared to the 2015 Kuantan Singingi Regency Head Election.

Then the response by the Chairperson of the General Election Commission of the Kuantan Singingi Regency, Irwan Yuhendi, ST, "For the stage of the Pilkada in Kuantan
Singingi Regency in 2020 during the Covid19 Pandemic yesterday, the implementation was in accordance with regulations from the Government, namely by referring to Government Regulation in Lieu of Law No. 1 of 2014 concerning the Election of Governors, Regents and Mayors. The impact on voter participation may be that there are some people who are worried about the spread of the Corona Virus and some people who choose not to come to the polling station in exercising their voting rights in the 2020 Kuantan Singingi Regency Election during the Covid-19 Pandemic."

Based on the results of an interview with the Chairman of the General Election Commission of Kuantan Singingi Regency, for the stage of Pilkada in Kuantan Singingi Regency in 2020 during the Covid-19 Pandemic yesterday, the General Election Commission of Kuantan Singingi Regency in carrying out its duties and functions refers to Government Regulation in Lieu of Law No. 1 of 2014 concerning the Election of Governors, Regents and Mayors. The 2020 local elections for Kuantan Singingi Regency began in 2019 before the Covid-19 pandemic. The implementation has been effective, because the KPUD and Bawaslu of Kuantan Singingi Regency carry out their duties and functions in accordance with the statutory regulations. For the implementation of the Bawaslu Health Protocol, it refers to PERPU No. 1 of 2020 concerning State Financial Policy and Financial System Stability for Handling the Covid-19 Pandemic.

Based on the results of an interview with the Chairperson of the Kuantan Singingi Regency Bawaslu, for the implementation of the 2020 Pilkada during the COVID-19 pandemic, it has been running effectively and maximally. Bawaslu carries out its duties and functions in accordance with statutory regulations, for the implementation of the Bawaslu health protocol referring to Government Regulation in Lieu of Law Number 1 of 2020 concerning State Financial Policy and Financial System 
Stability for Handling the Covid-19 Pandemic.

Then according to the Chair of the Kuantan Singingi Regency Bawaslu Mardius Adi Saputra, SH, the Kuantan Singingi Regency Bawaslu as a Supervisory Agency is indeed the responsibility of Bawaslu to carry out inherent supervision and monitoring of all election activities starting from the registration of regional head candidates, campaign activities and up to Voting. Another task for Bawaslu is to supervise the implementation of Health Protocols for Pilkada Organizers and the Community during the Covid-19 Pandemic, which refers to Perbawaslu No. 4 of 2020, Perbawaslu No. 5 of 2020, Perbawaslu No. 9 of 2020 and Perbawaslu No. 10 of 2020. Furthermore, according to academics at the Kuantan Singingi Islamic State University (UNIKS) Djumharis, S.Fil, M.Si, there were no socialization and education activities by the Election Organizer to universities and schools in the 2020 Pilkada. The public, assessed that the implementation of the 2020 Regional General Elections yesterday was not very effective, due to the lack of socialization to the public about the importance of implementing health protocols for the community and election organizers in the implementation of regional elections during the Covid-19 pandemic. To measure effectiveness in the Pilkada, it can be seen from the level of community participation and the level of public awareness in using their voting rights, whether the percentage of voters has increased or decreased compared to the previous Pilkada period.

\subsection{Lobbying}

Attempting to influence includes individual or group efforts to contact government officials and political leaders with the intention of influencing them on certain issues. According to the Chairperson of the Election Supervisory Body for Kuantan Singingi Regency, Mardius Adi Saputra, "there was no intervention and coercive action carried out by the Incumbent and the success team for the pair of regional head candidates to the public and the Election Organizer. measure whether there are reports from the public."

In the academic community, in assessing the candidate pair for Regional Head, the first point is the candidate's education level, the second is the academic experience and political experience of the candidate pair, if the level of education and experience is qualified, automatically an elected leader will be able to run the government system well. Factors that influence voter participation in the academic community at the Kuantan Singingi Islamic University are the education factor and political experience of regional head candidate pairs. Other factors that affect public participation in the election of the Regional Head of Kuantan Singingi Regency during the Covid-19 Pandemic, first, the lack of socialization from the Election Organizer to the public. Second, the economic factor where the impact of the spread of Covid-19 has a huge impact on the community's economy. Third, the public's concern about the spread of the Corona Virus where some residents feel reluctant to come to the polling station to exercise their voting rights in the 2020 Regional Head Election yesterday.

The public assesses the factors that affect Community Participation in the election of the Regional Head of Kuantan Singingi Regency during the Covid-19 Pandemic, namely the lack of socialization from the Election Organizer to the community, economic factors where the impact of the spread of Covid-19 greatly impacts the community's economy and public concerns about the spread of the virus where some residents feel reluctant to come to polling stations to exercise their voting rights in the 2020 Regional Head Elections during the covid-19 pandemic.

\subsection{Organizational Activity}

Organizational Activities, namely the involvement of community members in social and political organizations. Either as 
leaders, activists or as ordinary members whose main goal is to influence government decision-making. For the Voter Monitoring Agency, the General Election Commission of Kuantan Singingi Regency, had previously given accreditation to the institution in monitoring the implementation of the 2020 Regional Head Election yesterday. "For community organizations in Kuantan Singingi Regency, we hope that they will equally provide political education to the community."

Independent Voter Monitoring Committee, Community Organizations and others in providing political education to the public. The influence of a Community Organization on a person's political participation in exercising their right to vote in the Regional Head Election, of course there is an influence. If there are pairs of candidates for regional heads who are members of the management of an organization whose volume is quite large and if all of them move in order to provide support for one pair of candidates for regional head, this will certainly greatly affect the vote acquisition of the pair of candidates for regional head in the Pilkada of Kuantan Singingi District.

Based on the results of an interview with the Deputy Chairperson of the Kuantan Singingi Regency DPRD as Pilkada Activists, it was stated that "the influence of the organization on voter participation was of course an influence, because if the Candidate Pairs for Regional Heads joined in the management of an organization whose volume was quite large and if everything moved within the framework of providing support for one of the pairs of candidates for regional head, it certainly greatly affects the vote acquisition of the Candidate Pair for Regional Head in the Kuantan Singingi Regency Election in 2020 yesterday."

Organizational influence on voter participation, of course, exists because within an organization there are political interests that have an impact on the progress of the organization. Community organizations should be able to become a forum or place to socialize and educate the public regarding the implementation of the 2020 Regional Head Elections during the Covid-19 Pandemic.

\subsection{Contacting}

Seeking Connections, namely participation by the community directly with government officials or political figures, either individually or in small groups of people with the intention of obtaining benefits for a handful of people. Regarding political participation, people seeking connections are influenced by economic factors, because they have an impact on people's welfare. Another connection is through cultural, ideological and religious factors. However, it all depends on the political education of the people.

If the economy of a region is good, it certainly affects voter participation, cultural factors also affect voter participation because Kuantan Singingi Regency is a culture. Then the ideological and religious factors, in Kuantan Singingi Regency the majority of people are Muslim, this is certainly very influential on the participation and vote acquisition of the candidate pair for regional head.

This is also in accordance with the statement of the Chairperson of the Election Supervisory Body for Kuantan Singingi Regency, academics from the Kuantan Singingi Islamic State University (UNIKS) Djumharis, S.Fil, M.Sc. According to them, economic factors greatly influence public participation in exercising their right to vote in the Regional Head Election. Moreover, the situation during the COVID-19 pandemic has a direct impact on the community's economy. Although the consideration of the candidate's education level, the experience of the candidate pair, remains a concern for voters.

\subsection{Violence}

Violence is an attempt to influence government decision-making by means of 
violence that causes physical harm to people or property. During the regional head election activities in Kuantan Singingi Regency, anticipation was carried out by using various methods including social media registered with the General Election Commission of Kuantan Singingi Regency. KPUD through social media always delivers socialization and educations that educate the public regarding the implementation of the Pilkada and appeals to all levels of society to increase awareness of hoaxes that have an impact on the 2020 Kuantan Singingi Regency Pilkada process.

It must be admitted, nowadays, technological advances have almost reached all circles of society, especially those who already have an Android cellphone. Where all news and information can be known through social media, including information regarding the implementation of the Pilkada. However, in practice there are still violations of criminal, legal, administrative and code of ethics.

\subsection{Challenges}

As for the inhibiting factor in the implementation of the 2020 Kuantan Singingi Regency Head General Election during the Covid-19 Pandemic from the election organizers, the lack of budget for socialization activities. Where the budgeted amount does not meet the proposal and the limited activities of the community and election organizers during the Covid-19 Pandemic. The holding of the 2020 elections during the Covid-19 pandemic has challenges, both in terms of technical and quality of implementation.

The technical challenges of holding local elections during a pandemic are closely correlated with the procedures for organizing them at all stages of adjusting health protocols. Consequently, the General Elections Commission must be able to adapt it, one of which is for socialization activities. Socialization as an effort to convey political education to the public is a challenge for Pilkada organizers, namely how to encourage public awareness to use their political rights responsibly and vote rationally. In addition, of course, encouraging voters to come to polling stations by ensuring that polling stations are safe with the implementation of strict health protocols to prevent the spread of Covid-19.

Another obstacle is the lack of discipline in implementing public health protocols. The benchmark for the success of holding simultaneous regional elections on December 9, 2020 is determined from the enforcement of discipline in implementing health protocols so that there is no transmission of Covid-19 cases. This is the main responsibility of election organizers and all candidate pairs to ensure the 2020 Simultaneous Regional Head Elections can run smoothly and safely in the midst of the Covid-19 Pandemic, the General Elections Commission (KPU) has issued various regulations that emphasize the importance of implementing health protocols at all stages of the election. this time, including at the time of voting at TPS.

The General Elections Commission has set 12 health protocol kits at polling stations. Namely, hand washing stations, hand sanitizers, plastic gloves for voters, medical gloves for the Voting Committee Group (KPPS), masks, trash cans, face shields, temperature gauges, disinfectants, drip ink, hazmat clothes, and a special room for voters whose temperature is above 37.3 Degrees Celsius. Pilkada organizers are responsible for disciplinary enforcement of health protocols during voting, ensuring all individuals on duty wear masks, wash their hands and keep their distance. Officers are also obliged to remind voters to apply the same health protocol in a disciplined manner.

\section{Conclusion}

Based on the research and analysis that the author has done, it can be concluded that, regarding the lack of budget, the socialization of the implementation of the 2020 Regional Head Election during the Covid-19 Pandemic has not been very effective. The data that the author obtained 
from the General Election Commission of Kuantan Singingi Regency for the level of community political participation has decreased compared to the 2015 Regional Head Election Period.

Then, the education activities from the Election Organizers have not been optimal for the public about the use of voting rights and socialization about the importance of implementing strict health protocols in the implementation of the 2020 Kuantan Singingi Regency Election to prevent the transmission and spread of Covid-19.

\section{References}

Budiardjo, M. (2003). Dasar-dasar ilmu politik. Gramedia pustaka utama.

Gabriel A. (Mohtar Mas'oed:2011:57-58) Mas'oed \& MacAndrews (2008:225) Partisipasi Politik dalam jurnal (Andriyus: 2013;26) http://repository.uin-suska.ac.id

Hamdi, M. (2006). Jurnal Demokrasi dan Otonomi Daerah. Universitas Riau, Pekanbaru.

Huntington, S. P., \& Nelson, J. (1994). Partisipasi politik di negara berkembang.

Kartono, K. (1996). Pendidikan politik: sebagian dari pendidikan orang dewasa. Mandar Maju.

Kuswanto, K. (2020). Politik Hukum Pilkada Langsung.

Moleong, L.J. (2000). Metodologi Penelitian Kualitatif, Bandung, Remaja Rosdakarya.

Ndraha, T. (2003). Kronologi (Ilmu Pemerintahan Baru). Jakarta: Direksi Cipta.
Partisipasi Dan partai Politik. (1998). Jakarta: Yayasan Obor Indonesia.

Partisipasi dan Partai Politik: Sebuah Bunga Rampai. (1982). Jakarta, Gramedia.

Sanit, A. (1992). Aneka Pandangan Fenomena Politik GOLPUT, Pustaka Sinar Harapan.

Suryabrata, S. (2005). Metodologi Penelitian, jakarta: Raja Grafindo persada.

Tabloid Dayung Riau Edisi VIII. (2005).

Tjenreng, Z. B. (2020). Demokrasi di Indonesia Melalui Pilkada Serentak. Depok: Papas Sinar Sinanti. Widjaja, H. A. W. (2011). Otonomi daerah dan daerah otonom. 